\title{
Diversification of Nigeria Economy and National Development 2005-2012
}

\author{
Ibiam Sunday Mba \\ Department of Public Administration and Local Government \\ University of Nigeria, Nsukka \\ Eme, Okechukwu Innocent \\ Department of Public Administration and Local Government \\ University of Nigeria, Nsukka \\ Ihejirika Ngozi Obinnaiheji \\ Department of Public Administration and Local Government \\ University of Nigeria, Nsukka \\ Chidiebere Scholastica Nebo \\ Department of Public Administration and Local Government \\ University of Nigeria, Nsukka
}

Received: Feb. 21, $2021 \quad$ Accepted: Jun. 23, $2021 \quad$ Online published: Aug. 3, 2021

doi:10.5296/jpag.v11i3.18904 URL: https://doi.org/10.5296/jpag.v11i3.18904

\begin{abstract}
Economic diversification has been the only solution to Nigeria's economic challenges with the country in control of diversely untapped natural and human resources. This work has contextually x-rayed some much more considered theoretical paths of economic development through economic diversification and placed the blame for Nigeria's economic backwardness on political will and lack of commitment to national course of political leaders. Since the diverse policy process of the government had yielded little or no sustainable results, even when the emphasis is to utilize the potentials in non-oil sectors to benefit ever-increasing
\end{abstract}


population. Nigeria is relatively diversified but the positive impact of real diversification through surplus economic gains has not been achieved. A holistic approach to development was adopted in the theoretical framework used in this work that positively affects state, people and their relationship nationally and internationally. The thrust of the theory encourages free trade policy, efficient competition and democratic features to liberalize productivity through various guided legislation in line with Globalized Quality Standard. The research design was descriptive of the observed trend in the economy. It also analyses similar scholarly data collected for accuracy in exposing greatly a multi-sectoral approach in planning, dealing with interdependence using input-output matrix with reference to pre-independence and post-independence era of the national economy. This study looked at the positive intentions of some interventionist programmes and policies of the Government which were short-lived. Few years' aggregate contribution and sectoral real GDP rate were stated. Recommendations were effectively based on keen interest in multi-sectoral diversification of an economy being the sub-structure that determines the effectiveness of super-structure.

Keywords: diversification, multi-sectoral, development, gross domestic product, political leaders, economic sustainability, contributions, national planning, over-reliance, monolithic, policies, programmes

\section{Introduction}

Nigeria was very buoyant with revenue proceeds from agriculture, mining and later petroleum. Available statistics with the National Bureau of Statistics (NBS) shows that Agriculture was the main stay of the economy accompanied by mining and quarrying. Agricultural products like cocoa, palm oil, rubber and groundnut oil attracted about $90 \%$ foreign exchange earnings in 1960 to 1964 its contribution to the GDP was $61.65 \%$ and $53.27 \%$ in 1965 to 1970 . The extractive industry also made a significant contribution to the GDP between 1960-1970. In 1956 oil was still contributing little to the GDP but later in the year 1957, according to Nwankwo (1982, p.12); "it was only in December, 1957 that Nigeria began commercial production of crude oil. Before then, however, Agricultural proceeds had been used to ensure the development of basic infrastructures for economic development".

In the face of dwindling oil revenues it becomes mostly necessary for all hands to be on deck with a duty bound political will for the real diversification of the economy, via increased exports and government revenues which must accrue from every sectors of the economy as each sector is improved upon for optimum productivity. The problem of diversification in Nigeria according to Okoli (2004: p.192-3) revolves on Nigeria's planning arrangement. For him, "it seems indefensible for the third national development plan to lay greater emphasis on manufacturing and craft at the expense of agriculture, social welfare and rural development..." Some emerging subsectors of the entertainment and communication industries among others had recently shown the capability to contribute meaningfully at the present time.

According to Nwankwo (1982, p. 36-59) who looked at the condition of the oil producing countries and noted; "Iran has expended huge amounts on the importation of soviet arms and 
nuclear reactor from France. Still the economy is characterized by perpetual backwardness. Nigeria's story is not very different from those already cited."

He also acknowledged that Nigeria's only solution to the economic problem which had continued to enslave Nigerians to advanced economies of the world is to take up a movement for a determined policy reforms in diversifying her economy. Going back to agriculture increases the exportation of cash crops, cocoa, palm produces, groundnuts etc (Oyari, (ed) 2003). It is worst for a country that even imports most of the food she consumes. The industrial sector has also not been recognized because through the oil boom of 1970s no significant efforts were made by political leaders to establish industries which productively could take up from oil revenues should oil prices drop.

In the mist of plenty and later at a time of economic uncertainties, Nigerians at the helm of political affairs championed primitive accumulation without trying to align their thought with that of Dr. Nnamdi Azikiwe (1978, p. xi-xii) when he noted; "That neither capitalism nor socialism or welfarism has been practicable, in the sense of guaranteeing human freedom, social equality and economic security. Therefore Nigeria must break new ground by adopting the best element of these ideologies to re-orientate its primordial ideology". Our peculiar economic problems should find solution from environment giving of Nigeria multi sectoral wealth untapped. Not by any misguided aid and dictated recommendations from western economies and financial institutions of the World Bank and the IMF. We can put a stop to these economic crises via a multi sectorial and well developed economy. (Nwabugbiogu, 2016, Atahiru, 2007, Alex, 1998). Onwuemenyi (2012, p.6) agreed with what a mining expert and Chief executive of Rapids Mineral Resources, Mr. Ben Richards noted; "Minerals and metals exploitation is massive industry that brings in billions of dollars in revenue for many countries of the world, including Canada, Australia, and South Africa, where they have effective regulations to guide people's involvement in the industry. Nigeria is yet to enjoy the patronage that their metals and minerals sector deserve because of poor and ineffective regulations".

Poor budget implementation has also contributed to our present bad economic situation even when Nigerians should be flamboyant and proud of its solid mineral and mining sector rich with coal, gypsum, copper, zink etc (Olumide, et al, 2013, p. 692, Onwuemenyi, 2012).

In order to trace the pitfalls and be able to fine - tune measures that should be put in place for efficient diversification of Nigeria's economy far from oil driven economy with constant vulnerability to external price policies in an era of renewable energy search. This study is focused on improving government revenues via increase diverse exports and less importation to boast national development.

\section{Contextualizing Economic Diversification}

Nwankwo (1982) looked at diversification of economy as using the fortunes of oil boom and its later advantages to improve on Agriculture which is the main stay of Nigeria economy before the oil era. He pointed out that achieving food security will help Nigeria have balance of payment problems solved. He argued that only a radical process at changing her economic 
situation will succeed. More especially when approached through an economic revolution in ensuring that the manufacturing sector is sustained through reduction of imports and other heavy government openings possible under determined political institutions (Adamolekun \& Osuntokun).

The emphasis here concerning diversification of economy and economic development is that government should see the economy like they handle issues of security. The concept, good political governance is not only worthy objective only, it is also essential for providing the foundation for good economic governance, which is central to the process of economic growth and development (Adeyeye, 2007, Okafor, 2014, Nwabueze, 2001, Aja, 2001).

Chigozie \& Chukwudi (2015) precisely and more specifically captured economic diversification as the process of expanding the range of economic activities both in the production and distribution of goods and services. It is the widening of the economy to create opportunities for diverse economic activities to create a broad based economy. It provides job for wide spectrum of people and stabilizes the economy against economic fluctuations of commodities and sustains the development prospects of nations. Nigeria needs to use her huge oil revenue to diversify her economy to create job opportunities and satisfy the basic needs of her large population and sustain her quest for development. To achieve this, she has to conscientiously confront the challenges that may possibly or have been known to hinder economic diversification for a higher productivity (Baylis, etal. 2008, Chindo, 2011, Ezeani \& Elekwa, (ed) 2001).

From the above theses, diversification ensures that other sectors like manufacturing, transport, agriculture, tourism, specialized services, solid mineral etc. are developed to also play their part in its contributions of revenues to the government, so that in any case of external policies affecting the production and price of one sector, the other already established sectors can fill in the gap created by the current economic circumstance of one or two other economic sectors in a manner that will maintain equilibrium in citizens welfare (Dubem, etal, 2015, Richard, 2003). This agrees with the words of Yemi $(2016$, p.5) when he noted that; "prevailing economic situation has prompted Nigeria to work harder to further diversify our economy as well as government revenue".

However, almost half of the economy is informal and out of the (fiscal) control of government. He further argued that a report published in 2012 found out that about $25 \%$ of incorporated businesses in Nigeria through the corporate affairs commission were evading tax payment and about $40 \%$ tax payers was not constant. In line with the above maxim, Riti et al (2016, p. 64) posited that government is;

informed by the monolithic economy since 1980's which has been persistently threatened by the instability in crude oil prices in the international market, government has come to terms with the growing need for economic diversification. This economic transformation has become necessary to address the challenges of rising unemployment and social crisis by expanding the horizon of employment generating activities especially in the non-oil sector 
where the potentials remain great and largely unexploited. Government has, at various periods, put in place various policies which have impacted positively on the sector and contributed to the current growth status.

Evidently the diverse policy process that government go into to ensure the greater use of the potentials in non-oil sectors to drive the economy of a nation simply is referred to as diversification. Uzonwanne (2015, p. 61) describe it "as a collaborative effort of the government and other stake holders in seeking to increase the GDP and IGR for sustainable development". In this sense, however, diversification cannot be achieved by only the government, the civil society group (CSG) must be determined and challenged to partner. Chindo, (2011) noted that; it is not overdependence on petroleum economy the government democratically ensuring balance growth of the economy using economic scale available to any country. In order to achieve diversification there is a need for policy consistency, programme synchronization and co-ordination with a view to achieving overall macroeconomic stability under which the activities of the non-oil sector would flourish. This will ensure stable, social and political environment in order to sustain the momentum and determination to maintain such achievement over the years (Olurankinse \& Bayo, 2012, Nnoli, 2003, Okereke, 1999, Ajala, etal, 2015).Even when they existed various economic advancement programmes, the inherent ill of the use of oil money blinded everyone that the funds for these programmes were seen as wealth which was not gotten from hard earn sources. Spending spree attitude characterized every actor involved in programme execution. This scenario may be seen as a negative or dysfunctional aspect of development (Okoli, 2003, Ozor, 2004, Nnadozie, 2016). Third world countries are still battling with underdevelopment, Nigeria inclusive, this makes it very imperative for development and development planning that will cushion the effects of growth in population size which is inherent in any nation's life. It is noted that outrageous growth in population without better national planning strategy had reduced the quality of our education system such that students who are frustrated after graduation from our universities without getting suitable jobs (Okafor, 2014). This will make the victims transfer their anger to the socio-economic system that failed them. Their frustration results in armed robbery, gangsterism, kidnappingetc. and their victims are usually innocent Nigerians, (Agbodike as cited in Nnonyelu (ed) 2001, Udoji, 1999).

\section{Government has Critical Role in Economic Diversification}

More so, it was at the period of Rolling Plans that the Aggressive development was planned for, thus the establishment of Agricultural Development Programme (ADPs). The River Basin Development Authorities (RBDA) and feeder roads, National Directorate of Employment (NDE) in order to balance talents and job-opportunity creation. Even the Directorate for food and rural infrastructure (DFFRI). It is most glaring that the rolling plans had dealt with issues bordering on creating jobs, establishment of more infrastructures to enhance revenue and better spending guided by structural adjustment programmes SAP; Ensuring Macroeconomic stability through curtailment of unnecessary fiscal definition and a restrictive monetary stance, creating an opportunity for sustainable economic growth of about 5.5\% per annum (Anyanwu, 
etal, 1997,Chigozie \& Chukwudi, 2015, Anyanwu, 2000).

For the bold steps Nigeria had taken, more especially on Agricultural Transformation Agenda (ATA). Although they must be many challenges when Diversification is in process but significant investment is very necessary in human resources and infrastructure in order to support economic sectors, while measures are taken on issues of value addition commodities. These efforts are long term and it needs great commitment on the part of political leaders for new sectors to surface, collaboration and partnership is important. Government must be careful not to neglect fundamental traditional sectors for comparative advantage (Uzonwanne, 2015, Olurankinse \& Bayo, 2012, Aja, 1997). Diversification must embrace both the development of traditional historically attached economic base, that is, what a particular country is known to produce better than others and significantly from the main sources of revenue and foreign exchange earners of which it has a comparative advantage and orthodox economic structure which emerges as the world transits (Ogbonnta \& Onyike, (ed 2001, Apex, 2005).

As far as people and government are concerned, government has no time to waste rather it must step up revenue mobilization and reduce leakages. And focus on power, transportation and housing, it is expected that these key areas can create jobs and make people comfortable, on the other hand increase government revenue (Nwabugbiogu, 2016, Abogun, etal, 2016). The essence of governance is to meet up with the wishes and aspirations of the people, reaching out for more sources of income and revenues uplifts the living standards of the citizens when the government had achieved greatness in political economy.

In as much as factors could impinge on the supposed progress of non-oil sector for effective performance. Abogan, et al, (2016) suggests that government provides an enabling environment to correct the effectiveness and better functioning of these sectors eg. Industrial, agriculture and manufacturing. Boosting them will increase domestic output and effect positively the GDP while foreign exchange earnings will go higher and these policies that looks forward to boosting the non-oil export must be of paramount importance so that the country will not chiefly dependent on oil sector as the main stay and the largest contributor to the total government revenue and GDP. Funding and equipping the three sectors of Agriculture, manufacturing and industrial sectors will ensure better output andeconomic contributions. No doubt any sector or ministry that the government wants to be very viable than others can succeed because from the above suggestions the downturn of activities and low performance of many other sectors which had been the bedrock of our economy and subsequent oil price falls. Such conditions should have triggered a policy thought, challenging policy makers to make laws and ensure its execution in order to tap deep into the potentials of other sectors than oil for stability.

Diversification ensures that other sectors like manufacturing, transport, agriculture, tourism, specialized services, solid mineral communicationetc. are developed to also play their part in its contributions of revenues to the government, rrrrrrrrrrrrrrrrso that in any case of external policies affecting the production and price of one sector, the other already established sectors can fill in the gap created by the current economic circumstance of one or two other 
economic sectors in a manner that will maintain enhance citizens welfare (Anyaechie, etal, 2015, Adeyeye, 2007). This agrees with the words of Yemi (2016, p. 5) when he noted that; "prevailing economic situation has prompted Nigeria to work harder to further diversify our economy as well as government revenue". Real multi-sectoral economic development by the utilization of abundant natural resources as the only path for Nigeria economic progress.

\section{Theoretical Framework}

The theoretical framework for this study is Development theory propounded by Higgins (1968).In line with developmental strategies of the state through rich stable economic base; Development is associated to any efforts of the government and other well organized bodies or institutions in order to increase the standard of human welfare, while anything that undermines welfare is anti-development. And this will damage people's relationships, determination of the equality of life, destruction of traditional cultural values, increase inequalities, lead to poverty, unemployment and hunger (Higgins, 1968). Okoli(2003) sees development as very holistic improvement in all endeavour through available sectors in economic structure and the effects will undoubtedly be noticed in all aspects of human life; political, economic, social, cultural, international, etc.Political and economic development seeks system stability and system integration (Okoli, 2003,Okereke, 1999).

\section{Tenets of the Theory}

- The theory posits the use of policies to strengthen the economic base of the nation by allowing for competiveness to ensure higher returns through productivity.

- The roles of the state towards achieving richer economy rely on the mobilization of the consciousness and economic potentials for maximum growth.

- It is the right of people to enjoy good standard of living, so laws of the state should champion that course for national development.

- All the economic institutions and sectors must strive to avail themselves of states determination to ensure significant contributions to the GDP and GNP.

- Development is policy driven, for that reason all actors must view any developmental issues as constituting "National Interest".

- The general being of a states' life determines whether development has been effected or not since one-sidedness in advancement does not conclude development of a nation.

- It goes beyond the boundaries of ethnicity and elitism and encourages revenue from exports more than total payment for imports.

- Development theories embrace functional continuity of government policy implementation as against program and project abandonment even if such projects were initiated with good intentions and it has a proven potential to help in the diversification of the economic sector. 


\section{Application of the theory to the Study}

The application of the theory can be timely expressed as the Nigerian government has been affected adversely following dwindling prices of oil with its attendant economic recessions which had intermittently been recorded in Nigeria from 1981 to 1990. In 2014, we noticed from inception oil prices fall erasing the growth earlier recorded before then till 2014 and 2016. The theory emphasis is on government ensuring free trade, efficient competitiveness and democratic features of rule of law to enable these policies find their place in liberalizing productivity via various sectors for an added value in revenue from export goods and locally consumed products, these commodities compete with global quality standard (GQS).

Regulatory role of the government however attracts firms from advanced economies for third world countries if such is development oriented. For it will concentrate on the long-run change of favourable standard of living of the population.It will also ensure that sustainability is enshrined in government activities.

\section{Research Design}

The study is descriptive. It is concerned with the collection of data for the purpose of investigating the economic diversification and national development and the effect on over reliance on oil economy in Nigeria. This involved a more detailed facts finding endeavour through the use of relevant textbooks, journals, magazines, newspapers, internet, National Bureau of Statistics (NBS) bulletin, Central Bank of Nigeria (CBN) publications, World Bank Publications and some unpublished materials and online materials. These materials were used to compliment the primary data obtained by observing the Nigerian economy. These data were data analysed using content analysis to gain insight into the topic under investigation.

\section{Multi Sectoral Planning}

This type of planning, stresses, the interdependence among various sectors in an economy. It provides the link between macro and project planning. Much use is made of the input-output matrix (Anyanwu, et al, 1997). From the year 1945-1955 Nigeria although still under the hands of colonial masters was made to know the out- workings of multi-sectoral planning. The ten-year plan of development and welfare made emphasis on physical infrastructure (rail, roads, motor-roads, sea ports,etc. also public health expansion, education, services etc. these steps no doubt brought about the noticeable increase in productive capacity at that time. The second national development plan (1955-1960) took from the previous national planning arrangement and this time each regions worked out a path way and this resulted in all accelerated economic growth.

Under the first National Development Plan (1962-1968) an economic objective was formed by the federal, East, North and Western governments that make-up the regions. In order to facilitate planning for a common national development target and the establishment of such private sector-oriented development institutions as the Nigerian Industrial Development Bank (NIDB) was established (Usoro as cited in Anyanwu, etal, 1997).

The Second National Development Plan (1970-1974) had five long term objectives which 
include; (i) making Nigeria a self-reliant nation (ii) have dynamic economy i.e. one which must stand the test-of-time no matter oil/price falls. (iii) Just and egalitarian society, (iv) Nigeria, land of bright and full opportunity for all citizens i.e. the people of Nigeria will not look for where to do job for stipend in a way of unemployment and, (v) a free and democratic society. (Second National Development Plan 1970-1974, as cited in Anyanwu,. etal, 1797).

From the third National Development Plan (1975-1980) to the first National Rolling Plan in 1990-92, the second National Rolling Plan, 1991-1993, the Third National Rolling Plan, 1993-1995, the fourth National Rolling Plan, 1994-1996 \& The National Rolling Plan 1997-1999 this period is marked with military and civilian governance but one important issue is that increase in per capita income was represented, even distribution of income, reduction in the level of unemployment, diversification of the economy, etc.. All the above stated economic plans had its foundation on a well-diversified economy.

More so, it was at the period of Rolling Plans that the Aggressive development was planned for, thus the establishment of Agricultural Development Programme (ADPs). The River Basin Development Authorities (RBDA) and feeder roads, National Directorate of Employment (NDE) in order to balance talents and job-opportunity creation, and the Directorate for food and rural infrastructure (DFFRI). It is most glaring that the rolling plans had dealt with issues bordering on creating jobs, establishment of more infrastructures to enhance revenue and better spending guided by structural adjustment programmes SAP; Ensuring Macroeconomic stability through curtailment of unnecessary fiscal definition and a restrictive monetary stance, creating an opportunity for sustainable economic growth of about 5.5\% per annum. This will involve growth in the agricultural and manufacturing/industrial sectors and conducive environment for foreign direct investment (FDI) (Osuala, 2001, Anyanwu, et al, 1997). Diversification should have enlarged the sectoral responsibility to the revenues available to the government such that in any case of oil price fall all these other sectors of the economy will efficiently supply fund to government for its developmental activities. This will ensure National development not recession. In addition to the non-oil sector well improved upon, imported good will only be restricted to those that Nigeria has no possibility for its availability. While exportable products will be higher with international standard marketing mix. Nigeria economic dependence is as a result of the fact that policy makers are not rational in their approach to economic self-reliance. So the situation Nigeria finds herself shows that after these decades, all the resources and efforts expended is not yet sufficient to ensure development of these non-oil sectors and to efficiently provide for her citizens. The blame is on leadership problem (Obiegbu, 2005, Doggash, 2006). Improvement from traditional to science and technology led economy will solve these problems. It has been the line of direction in Nigeria before and after independence. Having seen a lot of opportunities in these sectors, the call now is for the government to consolidate its efforts continually so that the desired results will be objectively achieved. Our different sectors have showcased readiness to diversify our focus for national progress and development in the $21^{\text {st }}$ century. In line with Awa (1996, p.. 107-10) when he argued "that for us to rebirth means a move to overcome the problems of ignorance, poverty, disease and squalor even the ethnic orientation should give way for it is a negative content amongst the fruitages of national growth and development 
The life of ostentations need be changed so that the gap between the rich and poor can be closed (Njoku cited in Nwachukwu, 1995).

Diversification is evident in the sustained higher productivity output contribution to the GDP which provides surplus to be exported for exchange purposes resulting in more revenue to the government. The answer to the conscious hunch raised above is in the committed efforts of political leaders that economic policies are put in place, development oriented programme/laws are initiated and implemented strictly and regularly evaluated for effectiveness for results. Table 1 below captures this linkage:

Table 1. Aggregate contribution and sectoral real GDP growth rate 2003-2012

\begin{tabular}{|l|l|l|l|l|l|l|l|l|l|}
\hline Year & $\begin{array}{l}\text { Total } \\
\text { GDP }\end{array}$ & $\begin{array}{l}\text { Oil } \\
\text { GDP }\end{array}$ & $\begin{array}{l}\text { Non-oil } \\
\text { GDP }\end{array}$ & Agric & Manu & Extractive/Min & $\begin{array}{l}\text { Tel } \\
\text { comm. }\end{array}$ & Edu & $\begin{array}{l}\text { Business/other } \\
\text { services }\end{array}$ \\
\hline 2003 & 9.57 & 23.70 & 4.44 & 6.64 & 5.66 & 1.8 & 85.1 & 7.9 & 13.1 \\
\hline 2004 & 6.59 & 3.37 & 7.50 & 6.50 & 10.00 & 1.5 & 85.0 & 7.0 & 26.5 \\
\hline 2005 & 6.51 & 0.50 & 8.59 & 7.06 & 9.61 & 2.1 & 85.4 & 14.01 & 19.8 \\
\hline 2006 & 6.0 & -4.65 & 8.93 & 7.14 & 9.51 & 2.6 & 31.88 & 12.35 & 7.67 \\
\hline 2007 & 6.4 & 3.4 & 8.0 & 6.27 & 8.89 & 3.3 & 34.67 & 10.77 & 10.69 \\
\hline 2008 & 6.0 & 2.6 & 8.4 & 5.88 & 7.89 & 2.0 & 34.73 & 10.00 & 9.89 \\
\hline 2009 & 7.0 & 4.3 & 6.9 & 5.82 & 7.56 & 2.7 & 34.83 & 8.71 & 9.76 \\
\hline 2010 & 10.6 & 3.2 & 6.1 & 5.64 & 7.50 & 2.6 & 34.96 & 9.89 & 10.03 \\
\hline 2011 & 4.9 & 3.4 & 5.4 & 3.97 & 7.55 & 3.7 & 32.09 & 9.65 & 10.19 \\
\hline 2012 & 4.3 & -2.3 & 8.3 & 9.66 & 8.19 & 3.1 & 9.94 & 18.27 & 14.21 \\
\hline
\end{tabular}

Source: NBS (2014) and CBN (2014) statistical Bulletin modified by the Author

There have been fluctuations in the rate of sectoral growth contribution to the GDP. The result is unsteady rate of growth to help sustain efforts in ensuring added value of exports and national development. The GDP declined in 2011-2012 while oil GDP was courageous in 2003 but did less in 2012. Non-oil GDP performed in 2005-2008 but dropped and later took a gradual rise in 2012 with 8.3 while Agriculture rose to 9.66. Manufacturing had 10.00 in 2004 but later dropped and in 2012 which may be attributed to wrong policy implementation but had up to 9.66 in 2012. Tele communication was doing well in 2003-2005 but declined to about 9.94 in 2012 while education and business and other services experienced positive growth of 18.24 and 14.21 in 2012 respectively.

Nigeria has not been serious with economic diversification as a means to achieve real economic development which primarily manifests on the socio-political and economic status of the people.

It appears that our political leaders are yet to see economic planning with national development as a fundamental goal that must be achieve in other to defeat the main aim of their coming into power. The major instrument that government and in-fact political office holders over times use to stir up the wheel of development is well intended national developmental plan/law which respects no individual's views and aspirations (Oyari, 2003). If policies are made and the impact is not felt, the reassessment and further implementation is necessary not to jump into the formulation of other programs and policies and its enactment and implementation neglecting the former which has same intention and pursuit. Nigeria is 
good in initiating better economic policies and plans but effects of these policies are not examined or evaluated for reimplementation for results to be achieved. Another area of great concern is the issue of continuum in programme implementation. Regimes do not see reasons for proposed targets of their predecessors. This scenario left many good projects aimed at enhancing the living standard of the population and encourage even national growth to be abandoned, this leaders sees only personal accumulations via the projects not the general impact on development on the people. Also to be mentioned is the influence of foreign capitalists in their quest of using Nigerians at the helm of affairs who are neo-capitalists in accepting that Nigeria can always be a consumer nation not a producer nation (Nnadozie, 2016). The case of the collapse of previously achieved level of public enterprises geared towards economic diversification and productivity but disappeared through the prescription of IMF and the World Bank in their accusation that these enterprises constitutes wastages, should be a lesson to Nigerians (Seberu, etal, 2015). We must start and then transit to an economic height of advancement devoid of wastages and inefficiency. What are the possible ways forward? The next segment of the paper will address this puzzle.

\section{Recommendations}

\section{From the findings of this study, we recommend as follows:}

- The teaming unemployed youths should be empowered and posted to developed Farm settlements established by government while SMSEs be encouraged for growth through interest free loans and tax holidays.

- Development oriented laws, policies and programmes made should be evaluated to strictly achieve the target for which they were initiated in order to achieve national development. It will remove the Nigeria's bad image of good policies without positive impacts on the economy.

- Political leaders should as a matter of urgency de-emphasize revenue from oil but see the $21^{\text {st }}$ century as an era of petro-dollar crises and renewable energy which poses a challenge to countries depending on oil for National development. Following this trend, Nigeria must reinvest in Agriculture, industry/manufacturing etc. with full scientific and highly technological approach through the involvement of private sector management. This will undermined ethnicity and corruption which had been responsible for failures in economic planning and implementation.

- As Nigeria diversification index as at 2014 shows a decline, it calls for a more committed political will so that political leaders will be assessed for performance after their tenure. This will be based on the increase recorded in the diversification index annually for national development.

- Government should abolish the over- politicization of all policies and programmes aimed at embracing real diversification. This is normally known as; political farmers, investors and favouring the relatives of political leaders.

\section{Conclusion}




\section{Macrothink}

Journal of Public Administration and Governance ISSN 2161-7104 2021, Vol. 11, No. 3

Obviously, Nigeria is not relaxed in this situation ushered in by oil price fall and neglect to previously diversified economy, since it is clear that her planning process had missed some necessary steps which could have positioned the country. A look at Nigeria's economic policies shows that there is a lag between its regulatory policies which allows for the importation of some food even when Nigeria has all it takes to achieve greatness by mobilizing its human capital etc. The time for the search for those previously neglected sectors of the economy is now, everything in this era counts, for that political leaders should be able to exploit opportunities not thinking or relying on existing sources of revenue to the Government. Economic development cannot be achieved if sources of income remain static following inherent changes in life, the implication of this scenario is rather underdevelopment with a characteristic feature of low standard of living. Diversification seeks to ensure harnessing all available economic potentials through added value of exports for a better condition of living of the population.

\section{References}

\section{BOOKS}

Adamolekun, L., \& Osuntokun, J. (1977). Government and politics for West African students. Heinemann Educational.

Akpuru-Aja, A. (1997). Theory and Practice of Marxism in a World in Transition. Abakaliki: Williroe and Applesseed Publishing Coy.

Awa, E. (1996). Emancipation of AfricanLagos Emancipation Consultants and publishers Limited.

Anyanwu, J. C. et al, (1997).The Structure of the Nigerian Economy (1960-1997) Onitsha, Joanee Educational publishing Ltd.

Anyanwu, A. (2000).Dimension of Marketing Owerri, Avan Global publications.

Aja, A. A. (2001). Selected Themes in International Economic Relations Understanding Trends of globalization \& regionalization Enugu. Rhyce Kerex Publishers.

Attahiru, J. (2007). Democracy, Good Governance and Development in NigeriaIbadan, Spectrum Books Limited.

Baylis, J., Smith, S., \& Owens P. (2008).The Globalization of world Politics An Introduction to International relations New York, Oxford University press.

Ezeani, E., \& Elekwa, N. (ed) (2001). Issues in Urbanization and Urban Administration in Nigeria Enugu,JAMOE ENTERPRISES Nigeria

Egbo, S. (2003). Nigeria and the World a treatise on foreign policyEnugu, John Jacob's Classic Publishers Ltd.

Higgins, E. (1968). Economic Development London, Constable.

Nnamdi, A. (1980). Ideology for Nigeria: Capitalism, Socialism, or Welfarism? Lagos, MacMillan Nigeria publishers Ltd. 
Nwankwo, A. A. (1982).After Oil, What Next? Oil and multinationals in Nigeria Enugu, Fourths Dimension Publishing Co. Ltd.

Nnonyelu, N. (ed). (2001).Main Currents in Social Political IssuesEnugu, NGIB Publishers Ltd.

Nnoli, O. (2003).Introduction to Politics Enugu, Pan African Centre for Research on Peace and Conflict Resolution (PACREP).

Nwachukwu, C. O., \& Njoku, D. (1995).Public Educational Administration Owerri, Creative Educational Management Consultants.

Omoboriowo, A. (1982). Awoism Selected Themes on the Complex Ideology of Chief Obafemi Awolowo Ibadan, Evans Brothers Publishers Ltd.

Ogbonnata, C., \& Onyike, (ed), (2001). Modern Text in History and philosophy of science Owerri,Crystal Publishers.

Ogwu, J., \& Adebayo, O. (2001). The Economic Diplomacy of Nigerian State Lagos, Institute of International Affairs Nsukka, Great AP Express Publishers Ltd.

Ogwu, J., \& Adebayo, O. (2001). The Economic Diplomacy of Nigerian State Lagos, Institute of International Affairs Nsukka, Great AP Express Publishers Ltd.

Okoli, F. C. (2003). Politics of Development and Underdevelopment Theories of DevelopmentEnugu, Ingenious Creations services Ltd.

Oyari, O. O. (ed), (2003a). Development Administration in Nigeria Issues and Strategies Abakaliki, Willy Rose \& Appleseed Publishing Coy.

Oyari, O. O. (2003b). Public Policy Analysis \& Decision making Abakaliki, Willy Rose \& Appleseed Publishing Coy Abakaliki..

Ozor, E. (2004). Public Enterprises in Nigeria A Study in Policy Making in a Changing Political EconomyIbadan, University Press PLC.

Okafor, A. A. (2004).Poverty and human Development in Nigeria Challenges of the Millennium Development Goals.

Okoli, F. C. (2004) Theory and Practice of public Organization: A Book of ReadingsEnugu, John Jacob's Classic publisher Ltd.

Udoji, J. (1999). Which way Nigeria? Selected Speeches Ibadan, Spectrum Books Limited

\section{Journals}

Apex, A. A. (2005). "African in the face of Global Economy" 1 (1) 30-34 American Journal of International of Politics and Development Studies (AJIPDS).

Adeyeye, M. (2005).The Importance of Voting in the Process of Democratic Governance. The Electoral Journal, 1(1), 33-34. 
Apex, A. A. (2005). African in the face of Global Economy, 1(1), 30-34. American Journal of international Politics and Development Studies (AJIPDS).

Doggash, S. M. (2006).The role of the Legislature in Fiscal Discipline, 214-315. The Nigerian Legislative View.

Enuka, C. (2007). Contending issues in oil Revenue Allocation in Nigeria: Implication on National Integration, 1, 140-141. Nigerian Journal of Humanities and Social Sciences.

Obiegbu, J. N. (2005). Africa and the World in the $21^{\text {st }}$ century, 31 (1), 130-140.Nigerian Journal of International Affairs.

Omuoha, U. (2009). The political Economy of Economic Reform and Symptoms of Underdevelopment in Nigeria. Nigerian Journal of international community, 35(2), 110-112.

Ogbochie, A. (2010). Assessing Development plan in Nigeria, xv (2), 148-164The Case of Vision 20-2020.

Onyemaechi, O. J. (2010). Economic Relevance of the Theory of Comparative Advantage: Important Considerations in the Teaching and application of international Trade Theories in Developing Countries. African Journal of Social Policy and Administration, 3(1), 18-20.

Richard, J. (2001).State, Governance and Insecurity in Africa Democracy and Development, Journal of West Africans, 3(2), 12-16.

\section{Internet Sources}

Abogan, O. etal. (2014).Non-oil Export and Economic Growth in Nigeria (1980-2011) Retrieved from http://www.interesjournals.org/JREIF

Chindo, M. (2011). An Extensive Analysis of Mining in Nigeria using a GIS Retrieved from --wwwccsenet.org/jgg

Chugozie, M., Anyachie, A., \& Areji, C. (2015). Economic Diversification for Sustainable Development? Retrieved from http:/www.sciip.org/Journal/oips http//dx.doi.org/10.4236/01ps.2015.52010

Olurankinse, F., \& Bayo, F. (2012) Analysis of the Impact of Non- Oil Sector on Economic Growth Retrieved from net/index.php/css/article/viefile/J.css/1923669720120804.1222/2898

Olimide, S., Akongwale, S., \& Nnadozie, U. (2013). Economic Diversification in Nigeria: Any Role for Solid Mineral Development? Retrieved from www.mcsr.org/...351

Onodugo, F., Amujiri B. A., \& Nwuba B. (2015). Diversification of the Economy: A Panacea for Nigerian Economic Development.Retrieved from www.allsubj-ectjournal.com/../59

Riti, J.,Gubak D., \& Madina D. (2016).Growth of non-oil Sectors: a Key to Diversification and Economic Performance in Nigeria Retrieved From iiste.org/Journal/index: php/PPA R/articles/ view file/2967/30468

Suberu, O.,,Ajala, O., Akande and Adeyinka (2015). Diversification of Nigerian Economy 
towards a Sustainable Growth and Economic Development. Retrieve from http:/www science publishinggroup.com/j/ijefmdoi.11648/j.ijefm.2015 0302.15

Uzonwanne, C. (2015). Economic Diversification in Nigeria in the Face of Dwindling Oil Revenue. Retrieved from www.iiste.org

Yemi, K. (2016).Pushing Nigeria's Economic Development Forward: Issue \& Options Retrieved from www.nigeriastat.gov.ng/resource/op...

\section{Government Document and Report}

Central Bank of Nigeria. (Various years).Annual Report and Statement of Accounts. https://doi.org/10.5539/jgg.v3n1p3

Federal office of Statistics. (FOS).Annual Abstract of various years

IFAD, (2014). Community-Based Agriculture and Rural Development Programme. Retrieved from www. Research/chgate.net/publication/29...

National Bureau of Statistics (2016). Report on Nigerian GDP Quarter one. Retrieved from Nigeria stat gov.ng/download/398

Nnadozie, O. (2016).Public Policy for public interest and national Development in Nigeria: Whose Policy, Whose Interest and Whose Development? $112^{\text {th }}$ Inaugural Lecture of Nigeria press Ltd -UNN

African Development Bank Group. (2015).Economic Report on Nigeria Special Edition. Retrieved from www.afdb.org/3/ORNG-2015-pdf

\section{Magazine, Newspaper and Periodicals}

Abiodu, E. (2016, May 4). Economic Crises: How Nigeria Failed to Learn from History. This day

Nwabughiogu, L. (2015, October 6). Buhari Plans Diversification of Nigeria's Economy in 2016 Budget. The Vanguard

Nwanma, V. (2016, March 11). Nigeria Finally Embraces Economic Diversification. Global Finance Magazine

Onwuemenyi, O. (2012, August 02).Illegal Mining Reduces Nigeria's Take from Mineral Resources. Sweetcrude, Abuja

\section{Copyright Disclaimer}

Copyright for this article is retained by the author(s), with first publication rights granted to the journal.

This is an open-access article distributed under the terms and conditions of the Creative Commons Attribution license (http://creativecommons.org/licenses/by/4.0/). 